\title{
"T $\ddot{A} \ddot{A}$ ON KAIKKI IHAN SUN PARHAAKS" Koti, luokka ja sukupolvikonflikti elokuvassa Paha perhe (2010)
}

Artikkelissa tarkastellaan yhteiskuntaluokan asettamien odotusten aiheuttamaa sukupolvikonfliktia ja kodin hajoamista elokuvassa Paha perhe. Varakkaan perheen isän ja hänen aikuisuuden kynnyksellä olevan poikansa välistä konfliktia lähestytään isän arvojen siirtämisen kriisinä ja kriisiä seuraavana ihmisjätehuoltona, normaaliksi määrittyvää järjestystä haastavien ihmisten syrjä̈n sysäämisenä. Paha perhe on esimerkki nykyajan uusliberalismin menestymisen vaatimuksen tuottamasta tarpeesta hallita sitä, miten yhteisöön voi kuulua.

Aleksi Salmenperän käsikirjoittama ja ohjaama Paha perhe (2010) on musta komedia sukupolvikonfliktista ja isän pakonomaisesta pyrkimyksestä hallita sitä, miten hänen perheessään tulisi elää. Hallinta tulee esille heti elokuvan prologissa, joka alkaa lähikuvalla kameraan katsovasta miehestä (kuva 1). Taustalla soi rauhallinen kitaran säestämä, lasten soittorasiaa muistuttava kellopelimelodia, joka suoraan kameraan luodun katseen kanssa johdattaa meidät miehen pään sisään. Musiikki tuntuu jäljittelevän hänen ajatteluaan. Lähikuvaa seuraa elokuvan mustavalkoinen, mustavalkoista vastakkaisuuden asetelmaa ehdottava nimi "Paha perhe", minkä jälkeen näemme, että mies katsoo miekkailua. Kuulemme miekkailun ääniä, ja musiikkiin tulevat mukaan jouset. Fokus on miehessä, sillä edelleen hänen ajatteluaan ja näkökulmaansa korostava kellopeli soi voimakkaimpana.

Mies huutaa miekkailevalle pojalleen ohjeita. Poika kuitenkin häviää ottelunsa, ottaa miekkailukypärän päästään ja kävelee pois miekkailualueelta. Kuva ja sitä seuraava vastakuva katseista vihjaavat isän ja pojan hankalasta suhteesta: poika kääntää ärsyyntyneen näköisenä katseensa isään, jonka katse painuu kohti lattiaa (kuvat 2 ja 3). Kuva-vastakuva-leikkaus hämärtää jatkuvuusleikkauksen 180-asteen sääntöä, mikä tuo isän ja pojan suhteen särön näkyviin myös kerronnan tasolla.

Ohjeita huutanut mies on Mikael Lindgren (Ville Virtanen), hovioikeuden tuomari, jolla on lääkärivaimonsa Lauran (Veera Kiiskinen) kanssa kaksi poikaa, kymmenvuotias Milo (Niko Mäenpää) sekä miekkailemassa ollut kahdeksantoistavuotias Dani (Lauri Tilkanen). Dani on Mikaelin aiemmasta, 


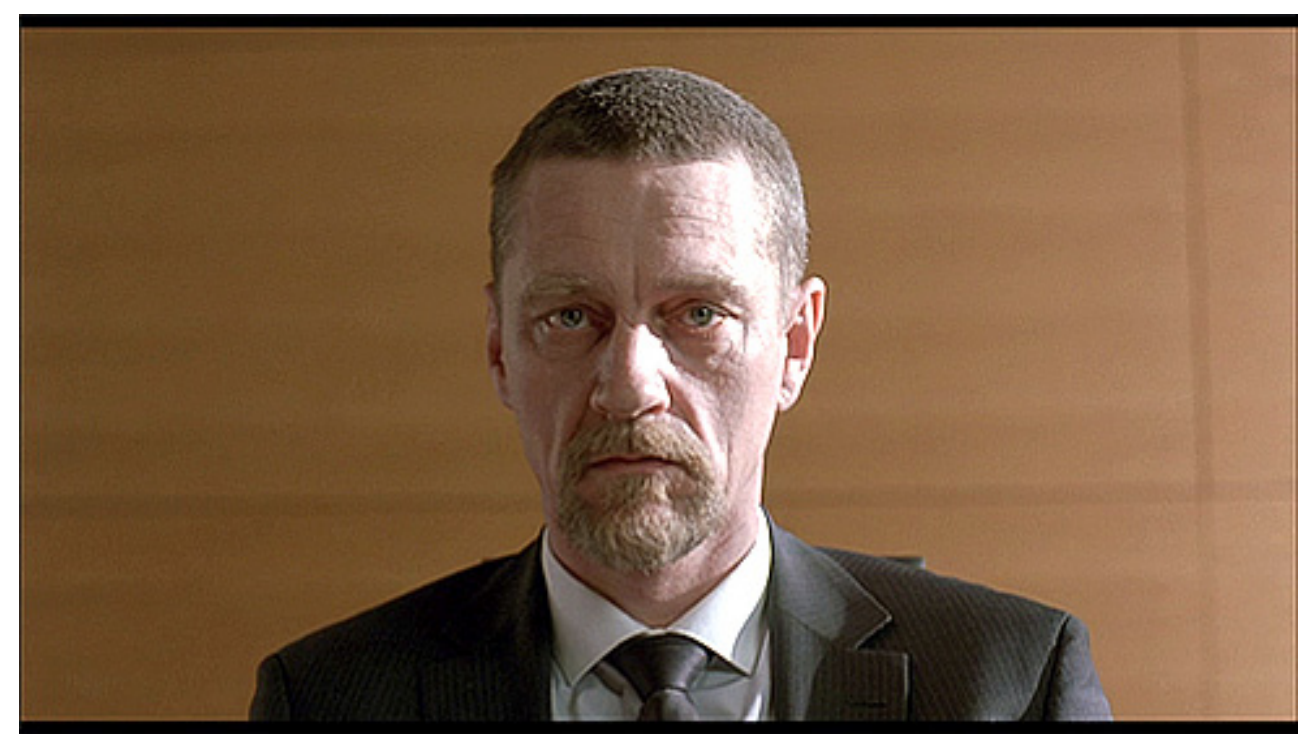

1 EG-luokittelu eli Robert Eriksonin ja John H. Goldthorpen (1992) luoma luokkaluokittelu on tämän päivän yhteiskuntatutkimuksessa eniten käytetty luokittelu. Siinä luokka-aseman keskeiset tekijät ovat ammatti ja status. (Erola 2010, 28-32; ks. myös Kontula 2016, 18.)
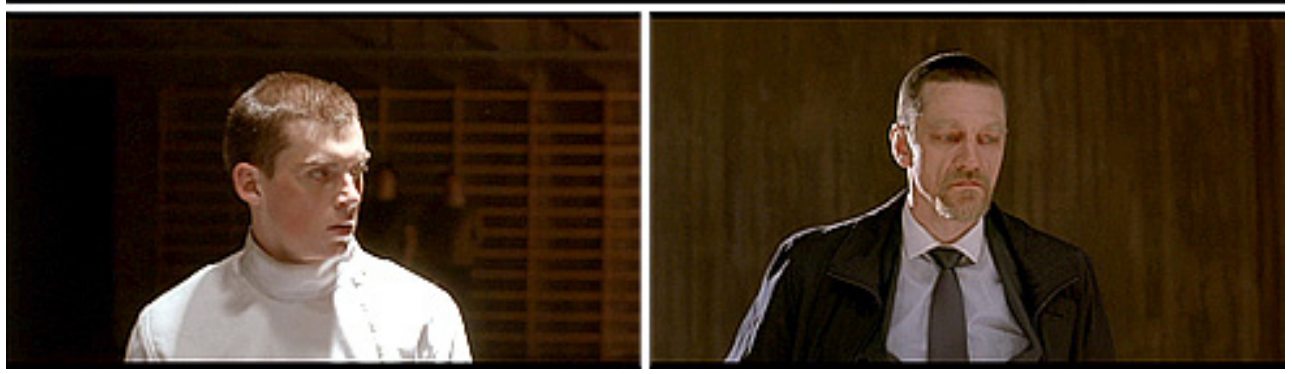

Kuvat 1-3 (kuvakaappaukset DVD:Itä). Paha perhe. Särö.

eroon päättyneestä avioliitosta. Danin siskoa Tildaa (Pihla Viitala) Mikael ei ole nähnyt sen jälkeen, kun Tilda muutti eron hetkellä lasten yhteisen äidin kanssa Tanskaan. Dani oli tuolloin kahden kuukauden ikäinen. Mikaelin perheeseen kuuluu myös heillä asuva Mikaelin puhekyvytön, Alzheimerin tautia sairastava isä (Ismo Kallio), jolla on oma hoitaja. Mikaelin ja Lauran ammatit asettavat perheen ylempään keskiluokkaan tai EG-luokittelun ${ }^{1}$ mukaiseen menestyvään eliittiin.

Prologi asettaa Mikaelin tilanteeseen, jossa hän joutuu miettimään suhtautumistaan poikansa "menestymättömyyteen". Kun miekkailukohtauksen lopussa paikalla katsojana olevan, pyörätuolissa istuvan Danin isoisän silmäluomet painuvat kiinni, on kuin hän tietäisi, mitä tästä seuraa. Miekkailutappioon liittyvät kolmen sukupolven ilmeet ovat kartta elokuvan esittämään sukupolvikonfliktiin, jonka lähtökohta on keski-ikäisen, ylemmän keskiluokkaisen perheen isän pelko siitä, ettei hän onnistu siirtämään pojalleen omia, kaikki elämänalueet toisiinsa kytkeviä, menestystä mittana pitämiään arvojaan.

Paha perhe on yksi esimerkki siitä, miten luokka ja uusliberalistinen menestymisen vaatimuksen eetos asettuvat 2000-luvun suomalaisen elokuvan kehykseksi. Tarkastelen niitä suhteessa perheeseen kuulumisen (belonging) esittämiseen. Elokuvan juoni käynnistyy, kun Dani herättää yöllä isänsä ja kertoo äidin kuolleen. Kun Tilda tulee Suomeen hautaamaan äitinsä, hän asettuu tahtomattaan katalyytiksi isän ja pojan orastavaan konfliktiin. Mikael kokee perheensä järjestyksen kyseenalaistuvan. Ylläpitääkseen haluamaansa 
järjestystä hän ryhtyy ulos sulkemalla määrittämään sitä, kuka hänen perheeseensä voi kuulua.

Lähestyn Pahaa perhettä luokkateknologiana, joka esittää ulos rajaavaa ihmisjätehuoltoa, ja kysyn, miten ja miksi elokuvassa neuvotellaan sukupolvikonfliktista suhteessa luokkaan ja isän ihmisjätehuoltotoimiin. Aloitan määrittelemällä ihmisjätehuollon ja luokkateknologian sekä sen, miksi uusliberalistinen eetos kehystää 2000-luvun suomalaista elokuvaa. Tarkastelen ihmisjätehuoltoa perheen tasolla, mutta artikkeli avautuu laajemmin kysymykseksi uusliberalistisen järjestyksen ideaalisubjektista ja seurauksista. Esitän, että isän toimet, jotka rajaavat perheeseen kuulumista, esittävät uusliberalistisen politiikan ja eetoksen johtaman nyky-yhteiskunnan pienoiskoossa.

\section{Elokuva ja ihmisjätehuolto}

2000-luku on suomalaisen elokuvan ajanjaksona erityinen ensinnäkin siksi, että 1990-luvun jälkipuoliskolla elokuvissa konkretisoitui katsojamäärien nousuun tähdännyt muutos. Siihen vaikutti oleellisesti Suomen elokuvasäätiön tukipolitiikka, joka alkoi 1990-luvun mittaan painottaa taide-elokuvan ja tekijän yksilöllisen ilmaisun sijaan markkinalähtöistä ajattelua (ks. Pantti 2005). Toiseksi 1990-luvun lopussa alkaneesta suomalaisen elokuvan buumista lähtien kotimaiset elokuvat ovat katsojamäärin mitattuna olleet meillä erittäin suosittuja. ${ }^{2}$ Koska elokuvat tavoittavat paljon yleisöä, niillä on potentiaalia vaikuttaa asenteisiin ja arvostuksiin.

Paha perhe avautuu luokkateknologiaksi samaan tapaan kuin Teresa de Lauretis (1980; 1987) tarkastelee elokuvaa sosiaali- ja tarkemmin sukupuoliteknologiana: elokuva voi heijastella tekohetkensä yhteiskunnallisia virtauksia, mutta se on ensisijaisesti representaatiokoneisto, joka ylläpitää tai kyseenalaistaa käsityksiämme esimerkiksi eritaustaisista ihmisistä ja eri asioista, kuten sukupolvikonfliktista, iästä ja yhteiskuntaluokista. Elokuvat ovat tässä prosessissa tärkeitä, sillä ne kertovat kulttuurisesti tuotetuista tavoista, joilla maailmassa olemisen ehtoja halutaan ja voidaan ymmärtää, ja ne voivat esittää vaihtoehtoisia tapoja ymmärtää vallitsevia yhteiskunnallisia virtauksia ja eetoksia (vrt. Bauman 2004, 16-17; Evans \& Giroux 2015, xiii; ks. myös Steinby 2008, 28).

2000-luvun uusliberalistisen markkina- ja kilpailueetoksen kehyksessä de Lauretisin näkemys elokuvasta ihmisiä representaatioin määrittelevänä teknologiana avaa yhteiskuntaluokan tarkasteluun mukaan ottamisen ja ulos rajaamisen näkökulman, joka muistuttaa Henry Giroux'n (2012) ajatusta uusliberalistisen politiikan harjoittamasta ihmisjätehuollosta (human waste management).

Giroux (2012, 18-19) määrittelee Yhdysvaltain kontekstissa 2000-luvun uusliberalistisen politiikan barbaariseksi kertakäyttökulttuuriksi, jonka oleellinen piirre on ihmisjätehuolto. Se on markkinaideologista toimintaa, jonka tarkoituksena on päästä eroon heikoista, yhteiskunnallista tukea tarvitsevista. Markkinavetoisessa järjestyksessä on taipumus nähdä suuri osa ihmisistä taakkana, koska politiikka on kiitollisuudenvelassa voiton maksimointiin tähtäävälle pääomalle (Evans \& Giroux 2015, 45; ks. myös Bauman 2004, 39; Steinby 2008, 42). Esimerkiksi silloin, kun valtiollisen politiikan johtotähtenä on taloudellinen kilpailukyky, ihmisjätehuolto näyttäytyy menestyksen saavuttamisessa ja ylläpidossa hallinnan tietoisena toimintana.
2 Vuonna 2015 kotimaisten elokuvien katsojaosuus oli peräti $30 \%$, mikä on toiseksi korkein Euroopassa (Suomen elokuvasäätiö 2016, 4). 
Luokkateknologian ja representaation politiikan näkökulmasta ihmisjätehuolto on läheinen Jonathan Bellerin (2006, 194-195) näkemykselle pääomaelokuvasta (capital cinema), joka pyrkii oman kerronnallisen aikatilajatkumonsa sisällä rajaamaan ulkopuolelleen kaiken ideologiansa vastaisen. Vaikka elokuva on yksiselitteisen määrittäjän sijaan neuvottelija, se osoittaa katsojalle position, josta neuvotteluun kannattaisi osallistua.

Ihmisjätehuolto ja pääomaelokuva määrittävät kahta toisiinsa kytkeytyvää ulottuvuutta, jotka vaikuttavat siihen, minkälaisena luokkateknologiana Paha perhe näyttäytyy. Ihmisjätehuolto liittyy ensi sijassa elokuvan sisältöön, jossa perheeseen kuuluminen määrittyy ulos sulkemisena. Pääomaelokuva taas viittaa ennen muuta kerrontaan eli siihen, miten elokuva haluaa meidän perheestä ulos sulkemiseen suhtautuvan.

Zygmunt Baumanin (2004, 30-31) mukaan ihmisten yhteenkuuluvuuden hahmottaminen ja ylläpito on suunniteltua, ihmisten luomien sääntöjen mukaista järjestyksen hallintaa, jossa suunnitelmaan kuulumattomat voivat määrittyä jätteeksi. Jätteeksi ajautuminen voi Baumanin mukaan olla osin modernin talouskehityksen sivutuote. Sen sijaan Brad Evans ja Henry A. Giroux (2015, 5, 47-49) määrittelevät uusliberalismin Baumanin näkemystä reflektoiden aktiivisesti organisoiduksi väkivallaksi. ${ }^{3}$ Siinä väkivalta on ihmisjätehuoltoa, jonka kohteena ovat menestymättömät.

\section{Menestys normaaliutena}

Paha perhe ponkaisee liikkeelle sukupolvikonfliktista, joka on fiktiivisen nuorisokuvauksen perusta. Menestyksen vaatimuksen ulottaminen perheeseen kuulumisen määrittelyyn tuo tarkasteluun uusliberalismikriittisen kulman. Mikaelin perheestä ulos sulkevat toimet tuovat perheessä esiin luokkien välisen suhteen, jota David E. James $(1996,5)$ nimittää marxilaisesti yhteiskuntasuhteen "piilotetuksi perustaksi". Oleellista Pahan perheen asetelmassa on, että vaikka se tekee luokkajaon näkyväksi, se asettaa luokat yksipuoliseen, Mikaelin päänsisäiseen konfliktiin, joka ajaa hänet käyttämään valtaansa. Elokuva on myös esimerkki siitä, että pikemmin kuin abstraktiin omistajuuteen, luokkasuhde perustuu kykyyn tai mahdollisuuteen hallita toisia omaksi eduksi (Eagleton 2011, 171).

Pahassa perheessä perhe ei elokuvan nimestä huolimatta ole varsinaisesti paha. Paha on perheen isän oletus siitä, miten "normaalissa" perheessä tulisi elää. Mikael yrittää kontrolloida lapsiaan ja koko perhettään, jotta se pysyisi hänen mielessään käsikirjoittamansa maailman rajoissa (ks. Chambers 2001, 27). Tuo normaaliksi määrittyvä ja rajattu maailma on ylemmän keskiluokkaisen ydinperheen menestystarina, jossa vanhemmat ohjaavat lapsiaan kohti hillityn käytöksen ja oman aatemaailmansa jatkuvuuden turvaavaa aikuisuutta (ks. Griffin 1993, 90, 93).

Uusliberalismin taloudellista menestystä ja kuluttajuutta palvovassa järjestyksessä luokalla ajatellaan jotenkin automaattisesti työväenluokkaa, kun taas yhteiskunnallisena normaaliutena määrittyvää, kuluttamaan kykenevää keskiluokkaa ei useinkaan ymmärretä samalla tavalla luokaksi (Dave 2007, 163; Skeggs 2004, 7). Pahan perheen ylemmän keskiluokan perhe on kuitenkin luokaton vain näennäisesti, sillä elokuva esittää "luokkataistelun" yhden perheen sisällä. Perheen sisäinen kamppailu avautuu tarkasteltavaksi uusliberalismin vaikutuksena käytökseemme ja identiteettiimme. Koska ihminen on sopeutuvainen, merkittävät ympäristössä tapahtuvat muutokset vaikut-
3 Vaikka inmisjätehuolto tuntuisi sanana metaforiselta, se viittaa aktiivisiin toimiin, joilla inmisiä suljetaan yhteiskunnan ulkopuolelle. Tätä seuraten myös elokuvan, jonka tekeminen perustuu aiheen valinnasta ja käsikirjoittamisesta lähtien lukuisiin toisiinsa vaikuttaviin valintoihin ja ulos rajaamisiin, voi ajatella jonkin asian neuvotteluun osallistuvaksi väkivallan muodoksi.

Elokuvan teknologiaan liittyvän väkivallan tai jätehuollon tarkastelussa on kaksi toisiinsa liittyvää perusaskelmaa: representaatio ja kerronta. Esimerkiksi silloin, kun tarkastelemme yhteiskuntaluokkia elokuvassa, tärkeätä on ensin se, ilmenevätkö luokkajaot jotenkin merkitsevästi elokuvan tarinassa. Jos luokalla ei ole merkitystä, elokuva saattaa luokka-asemien olemassaolon ja merkityksen kyseenalaistamalla toimia jätehuoltona teeman tasolla. Kun luokkajako näkyy ja korostuu, elokuva valitsee todennäköisesti luokkateknologiana puolensa. 
tavat myös käytökseemme, tapaamme toimia (Verhaeghe 2014, 104). Mikä tuo Pahassa perheessä ilmenevä uusliberalismin tuottama muutos sitten on?

Vuonna 1979 Michel Foucault (2008, 226-227) erotti liberalismin ja uusliberalismin käsitteellä homo economicus. Klassisessa liberalismissa käsite viittaa subjektin toimimiseen taloudellisen vaihdon osapuolena. Runsaan kolmenkymmenen vuoden aikana kehittyneessä uusliberalismissa ei enää olekaan ensi sijassa kyse vaihtokumppanuudesta, sillä homo economicus on "itsensä yrittäjä (- -) itse oma pääomansa, tuottajansa ja ansioidensa lähde". Paul Verhaeghen $(2014,74-75)$ mukaan vuosituhannen vaihteen tienoilla tällaisessa yksilön korostamisessa siirryttiin itsen löytämisestä itsen täydellistämiseen. Siinä menestyksestä tuli kaiken mitta. Uusliberalistisella eetoksella tarkoitankin juuri menestymisen vaatimusta ja sen toisena puolena epäonnistumisen kieltämistä.

Pahan perheen prologissa aloittama jatkuvuuden ja arvojen siirron neuvottelu voimistuu prologia seuraavassa kohtauksessa, jossa epäonnistumisen kieltäminen nousee keskiöön. Mikaelin nuorempi poika Milo kysyy kotona isältään, onko tämä joskus tuomarintyössään tuominnut syyttömän vankilaan. Mikael sanoo olevansa "sataprosenttisen varma", että kaikki hänen tuomitsemansa ihmiset ovat olleet syyllisiä.

Mikael kieltää epäonnistumisen mahdollisuuden, vaikka hän ei voi olla täysin varma kaikista antamistaan tuomioista. Hän esittää erehtymätöntä vanhempaa. Kenties hän kieltää mahdolliset väärät tuomiot uusliberalismin muovaamana yksilönä myös siksi, että yksilöllisessä kilpailussa jokainen epäonnistuminen on heikkous, joka tekee haavoittuvaksi ja voi siten kohdistua itseä vastaan (Verhaeghe 2014, 206). Mikael vie ajatuksen kasvatusmielessä hölmöyteen asti, kun hän ei voi myöntää omille lapsilleenkaan, että hänen epäonnistumisensa olisi mahdollista. Keskustelun keskeyttää Dani, joka ohi kävellessään ilmoittaa lopettavansa miekkailun, "sen pelleilyn". Lausuma tuo mieleen väkinäisen jatkuvuuden, sillä miekkailu tuntuu isän pojalleen osoittamalta harrastukselta.

Danin ilmoituksesta käydään isän ja poikien välillä lyhyt keskustelu, jossa nousee esiin keskiluokkaisuutta positiivisesti määrittäviä piirteitä. Miekkailussa koettu tappio - ja varsinkaan luovuttaminen - ei kuulu Mikaelin menestyksen maailmaan, jota määrittää erityisesti päämäärätietoinen yritteliäisyys (ks. Lahikainen \& Mäkinen 2012, 8). Yritteliäisyyteen liittyy oleellisesti vielä periksiantamattomuus, johon vetoamalla Mikael yrittää kääntää Danin pään miekkailun jatkamisen kannalle: "Jos antaa periks periksantamiselle, ni pian ei enää muuhun pystykään." Kyse on jälleen jatkuvuudesta, mihin viittaa erityisesti Lauran kommentti miehensä itämaiselta viisaudelta kuulostavaan aforistiseen lohkaisuun: "Sähän alat kuulostaa ihan isältäs sillon ku se vielä puhu."

Uusliberalismissa jokainen on yrittäjä ja oma pääomansa. Verhaeghe $(2014,163)$ korostaa, että erityisesti nuorten on pärjätäkseen ajateltava itsensä "yrityksiksi", joiden on koko ajan pyrittävä lisäämään markkina-arvoaan erilaisilla tiedoilla ja taidoilla. Tällainen taito voisi olla myös isän pojalleen haluama miekkailu, jolla on moniin muihin lajeihin nähden pienemmän harrastajamäärän yksilölajina massasta erottautumisen mahdollisuus. Kun Dani ilmoittaa lopettavansa miekkailun, Mikael kokee epäonnistuneensa, sillä koska vanhemmat ovat vastuussa lapsistaan, heidän on jatkuvuutta painottavassa järjestyksessä otettava vastuu niin lastensa onnistumisista kuin epäonnistumisistakin (Verhaeghe 2014, 191). 
Uusliberalismissa politiikka ja talous kytkeytyvät erottamattomasti toisiinsa, mutta ennen kaikkea siinä on kyse ihmisenä olemisen ideaalin muuttumisesta ja ihmisenä olemisen hallinnasta (Read 2013, 26-27). Äärimmilleen vietynä hallinta tarkoittaa sitä, että kun kaikki elämänalueet saatetaan markkinoiden piiriin, joka tunkee menestyseetoksen kaikkialle (esim. Harvey 2005, 18), se ajaa arkisissakin tilanteissa pohtimaan omaa käytöstä ja toimintaa sijoitusten, panostusten ja niillä saavutetun tuoton näkökulmasta (vrt. Smith 2015, 37; Steinby 2008, 44). Tällöin ihmisten väliset suhteet voivat näyttäytyä epätasa-arvoista hyötyä osoittavina tavarasuhteina. Tämän Mikael on sisäistänyt. Luokka näyttäytyy Mikaelin haluaman järjestyksen pakottavana ylläpitona, johon muut perheenjäsenet joutuvat mukaan, koska he ovat oleellinen osa Mikaelin ulospäin näkyvää menestystarinaa.

Verhaeghen $(2014,180)$ mukaan jatkuva kilpailu ja menestymisen vaatimus pakottavat meistä esiin huonoimmat puolemme, jollainen on esimerkiksi kyky valehdella vakuuttavasti. Uusliberalistisessa meritokratiassa, jossa jokainen on "oman itsensä herra" ja kaikki kilpailevat kaikkia vastaan, valehteleminen houkuttelee, eivätkä toisen asemaan asettuminen tai tarve auttaa muita vailla omaa etua kuulu hyveisiin. Verhaeghen mainitsemiin huonoimpiin puoliin kuuluvatkin oman edun tavoittelu ja toisen näkeminen oman menestystarinan välikappaleena. (Ks. ibid., 166, 174-175.)

Jos lähdemme siitä, että jokainen yhteiskunta pyrkii määrittämään sen, mikä ymmärretään normaaliksi ja mikä epänormaaliksi, Verhaeghen esittämiä huonoimpia puolia ja niiden vaikutusta voi tarkastella juuri normaaliuden neuvottelun, määrittelyn, tuottamisen ja haastamisen näkökulmasta.

\section{Järjestys ja häiriö}

Pahassa perheessä nykyhetkeä määrittää perheen ulkopuolelle sijoittuva menneisyys, joka tuottaa perheen luokkajärjestystä ylläpitävälle Mikaelille pelkoa ja ahdistusta. ${ }^{4}$ Nykyisyys ja menneisyys törmäävät, kun Dani herättää yöllä isänsä ja kertoo äidin kuolleen. Mikael on yrittänyt unohtaa epäonnistuneen menneisyytensä, jota hän nyt joutuu käsittelemään. Törmäys voimistuu, kun Tilda, jonka Mikael on jo kerran sulkenut maailmansa ulkopuolelle, tulee Suomeen äitinsä hautajaisiin.

Lopullisesti Mikaelin varjelema järjestys järkkyy, kun Dani ja Tilda nopeasti lähentyvät toisiaan. Tilda on Mikaelille järjestyshäiriö, normaaliuden, keskiluokkaisten arvojen menettämisen uhka. Jos pojat ajattelee "isien omaisuudeksi" ja heidän työnsä jatkajiksi (Varto 2002, 171), Mikael pelkää normaaliuttaan määrittävän jatkuvuuden katkeavan. Syynä on kuvitelma, että Danilla ja Tildalla, jotka tapaavat toisensa ensimmäistä kertaa, on seksisuhde. Mikaelin mielikuvitus alkaa laukata, kun sukutapaamisessa perheen ulkopuolinen, Kari (Tomi Salmela), yllyttää häntä lastensa tarkempaan kontrolliin. Kari redusoi nuoruuden seksuaalisuuteen ja harkitsemattomuuteen ja saa Mikaelissa aikaan moraalisen paniikin.

Sukutapaamisesta pois lähtiessä Mikael pakottaa Danin ajamaan, jotta tämä ei voisi istua Tildan vieressä takapenkillä. Mikael repii poikansa väkisin takapenkiltä auton rattiin, vaikka tällä ei ole vielä ajokorttia. "Pidetään sellanen koti-inssi, kenraali", poikansa ajo-opettajana toimiva Mikael toteaa. Kuljettajan paikalle pakotettu Dani peruuttaa täyttä vauhtia takana olevan auton kylkeen ja kysyy ilmeenkään värähtämättä: "Reputiks mä?" Kolaroimalla Dani osoittaa isältä-pojalle-jatkuvuuden katkenneen.
4 Epävarmuuden tuottamaa keskiluokan ahdistusta on tarkasteltu aiemmin useiden eri lajien elokuvissa. Esimerkiksi Douglas Kellner (1996) tarkastelee 1980-luvulla tehtyjä, yliluonnollista, perheen ulkopuolelta nousevaa kauhua esittäviä Poltergeist-elokuvia (USA 1982-1988) amerikkalaisen keskiluokan pelkojen ja epävarmuuden allegoriana. Paul Dave (2007) taas analysoi urbaania draamaa Sliding Doors (USA 1998) esimerkkinä keskiluokkaisuudesta epävarmuuden määrittämänä taisteluareenana. 
Mikael tulee pakkomielteisyytensä takia nöyryyttäneeksi itseään, kun hän isänä ja ajo-opettajana epäonnistuu muiden silmien edessä. Kolaroinnin jälkeen kotiin ajetaan rikkinäisellä autolla, joka on konkreettinen merkki järjestyshäiriöstä, epäonnistumisesta ja perheen murtumisesta. Matkaa säestää prologista tuttu kellopelimusiikki. Musiikki peittää kaikki muut äänet alleen ja ohjaa meidät näin jälleen Mikaelin ajatuksiin. Hänen maailmanjärjestyksessään pahinta tapahtuneessa on, että hänen epäonnistumistaan olivat todistamassa hänelle läheiset ihmiset, joiden tulisi ajatella, että hänellä on kaikki hyvin.

Sosiaalinen maailma on presuppositioiden maailma, jossa ryhmiin kuulumista ohjaavat ääneen lausumattomat erilaisin toistuvin toimin, rituaalein ja mallein rakennetut ehdot (vrt. Bourdieu 2013, 92). Perheessä nuo ehdot muodostavat kuulumisen perustan, joka syntyy ja lujittuu tavallisesti vanhempien määrittämiä malleja ja käytäntöjä performatiivisesti toistamalla (vrt. Bell 1999, 3.) Paha perhe korostaa, että perheeseen kuuluminen ei ole tasa-arvoista, sillä sukupolvihierarkia tekee siitä lähtökohtaisesti epätasa-arvoisen. Perheeseen kuulumisen ääneen lausumattomat ehdot tulevat Pahassa perheessä esiin, kun niitä Mikaelin mielestä - tai paremminkin mielessä - rikotaan. Tällöin rikotaan vallassa olevan asettamia sosiaalisia normeja (ks. Verhaeghe 2014, 209).

Jos koti rakentuu voimakkaan hierarkkisesti eikä anna tilaa nuoren näkemyksille ja mielipiteille, se mitä todennäköisimmin kannustaa nuorta erottautumaan perheestä (esim. Douglas 1991, 287). Koska perhe ohjaa keskeisellä tavalla talouteen, politiikkaan, seksuaalisuuteen ja muihin yhteiskuntajärjestyksen kannalta tärkeiksi koettaviin arvoihin suhtautumista, (esim. Griffin 1993, 159; ks. myös Dimmock 2005, 192-193), kuten Pahassa perheessä, ei ole ihme, että koti ja perhe näyttäytyvät elokuvissa usein sukupolvikonfliktin tilana, jonka kuulumisen määrittely aiheuttaa.

Usein on esitetty, että median nuorisokuvaukset kertovat aikuisten ja yhteiskunnan tarpeesta määritellä ja kontrolloida nuoria (esim. Bourdieu 1985; Römpötti 2012). Tällöin nuoren representaatiossa on kyse vanhempien ja yhteiskunnan asettamista toiveista ja odotuksista. Jos nuori ei kykene toimimaan odotusten mukaisesti, hänet voidaan esittää pahana, pelottavana ja siten "epänormaalina". Näin osoitetaan, että nuorta on tarpeen ohjata ja kontrolloida. (Vrt. Verhaeghe 2014, 153, 148.) Näin elokuva myös toimisi ideologisena representaatiokoneistona.

Pahassa perheessä Dani toimii isän järjestyksen vastaisesti. Genrevalinnallaan elokuva kuitenkin väistää uusliberalismin pönkittämisen, sillä isän pojalleen osoittama menestystarina esitetään mustana komediana. Dani ei halua toteuttaa isänsä määrittämää menestystarinaa tai toimia isänsä menestystarinan osana. Genreristeyksissä eli paikoissa, jotka ehdottavat draamaan komediallista ymmärrystä, Paha perhe haastaa luokkateknologiana vallitsevan järjestyksen esittäessään ylemmän keskiluokan perheen isän vaatiman järjestyksen pakottavana, kiusaavana ja naurettavana.

Taantumuksellisesti ajatellen Pahan perheen sukupolvikonflikti olisi kertomus siitä, mitä tapahtuu, kun ydinperhemalli järkkyy. Ydinperheen malli on neuvottelun kohteena kuitenkin jo lähtökohtaisesti, sillä Deborah Chambersia $(2001,66)$ lainaten Mikaelin perhe on toimintahäiriöinen (dysfunctional), toiseuteen viittaava yksikkö, joka populaarikulttuurin nykyarjen kuvauksissa esitetään usein tragikoomisena. ${ }^{5}$ Pahassa perheessä moraalin kadottavan isän mielikuvituksen toimintahäiriö hajottaa perheen pysyvästi ja tekee siitä epäonnistuneen rakennelman, jonka syynä on hänen mielessään sukupuolittunut menneisyys.
5 Toinen, alemman yhteiskuntaluokan maailmaan sijoittuva kotimainen uusliberalismiin kytkeytyvä tragikomediaesimerkki on hajonneen työväenluokkaisen perheen elämää kuvaava Päin seinää (Antti Heikki Pesonen, 2014). Se menee komediallisuudessaan niin pitkälle, että se tuntuu köyhyyden kulttuurin teesin mukaisesti väittävän henkilöiden olevan moraalittomia ja itse vastuussa epäonnistumisistaan. 


\section{Menneisyys on jätettä}

Menneisyyden negatiivinen tapahtuma eli avioero, jonka Mikael esittää Danin äidin syyksi, laukaisee Mikaelin ihmisjätehuoltotoimet. Mikael on sulkenut elämästään pois menneisyyden, jota hän ei kyennyt hallitsemaan. Se on hänelle jätettä, joka on yritettävä pitää piilossa, koska se kertoo hänen epäonnistuneen.

Menneisyydestä ponkaiseva ihmisjätehuolto tekee perheen järjestyksestä voimakkaasti sukupuolitetun. Tämä käy selväksi, kun Dani tulee yöllä kertomaan isälleen äidin kuolleen. Dani istuu sängyn vieressä tuolilla, herättää isänsä ja sanoo asiansa. Näemme Danin kuvan etualalla, mutta Mikael ei nouse sängystään ja esimerkiksi lohduta poikaansa, mikä tuntuisi isälle sopivalta käytökseltä. Hän vain makaa sängyssään ja toteaa kuin mihin tahansa kuulemaansa: "Okei." (Kuva 4.) Kun Dani isänsä lakonisen vastauksen jälkeen kävelee pois huoneesta, kamera pysyy paikallaan ja kuvarajaus samana. Menneisyyden jäteluonne, Mikaelin unohtamisen aktiivisuus, tehdään selväksi, kun Laura nousee Mikaelin selän takaa ja kysyy, kuka on kuollut (kuva 5). Mikael vastaa päätään kääntämättä selkä Lauraan päin: "Ei kukaan." Mikaelille kariutunut avioliitto, ja kaikki sen mukana kahdeksantoista vuotta sitten perheen miesten (Mikael ja Dani) ulkopuolelle rajattu, ei ole enää ollut olemassa.
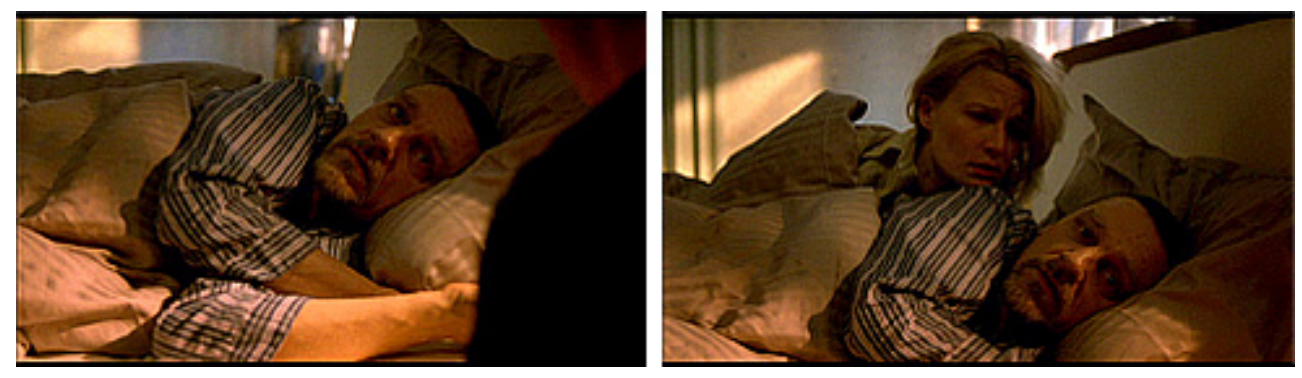

Kuvat 4 ja 5 (kuvakaappaukset DVD:Itä). Paha perhe. Menneisyys iskee.

Erossa kaksivuotias Tilda muutti äitinsä kanssa Tanskaan ja kaksikuukautinen Dani jäi asumaan isänsä kanssa. Mikaelin mukaan Danin äiti jätti perheensä äitiyslomalla Mikaelin rokkariksi määrittelemän toisen miehen kanssa, koska "ei kuulemma pystynyt hengittämään" ${ }^{6}$ Mikael on avioerossa jätehuoltanut omasta mielestään epäonnistuneen avioliiton syyn, Danin äidin ja hänestä muistuttavan tyttärensä, pois Suomesta. Kun Tilda tulee Suomeen, Mikaelin hyvä-paha-akselilla mielessään sukupuolittama maailma järkkyy.

Järkkymistä seuraavan perheestä ulosrajaamisen Mikael aloittaa, kun Laura saattaa hänet hautausmaalle. Mikael pyytää Lauraa yöpymään Milon kanssa yhden yön hotellissa. Pyyntönsä lopuksi hän viittaa tyttärensä läsnäoloon epänormaalina tilana: "Lentää varmaan huomenna takasin. Päästään normaaliin päiväjärjestykseen."

Haudalle kävellessään Mikael jää ensin seisomaan etäälle, kun hän näkee Danin ja Tildan seisovan yhteisen äitinsä haudalla. Haudalla kohtaukseen tulee absurdi vire, kun Mikael lukee kukkiin kiinnitetyn muistovärssyn kuin kenelle tahansa vieraalle ihmiselle. Dani on valinnut puolensa: hänen ja Tildan katseet kohtaavat, kun he tuijottavat tavanmukaista hautajaisiin osallistuvan rituaalia suorittavaa isäänsä haudan toiselta puolelta (kuva 6).
6 Elokuvassa käsiteltävän seksuaalisuuden teeman kannalta humoristisesti rokkarin yhtyeen nimi on Motherfuckers. 


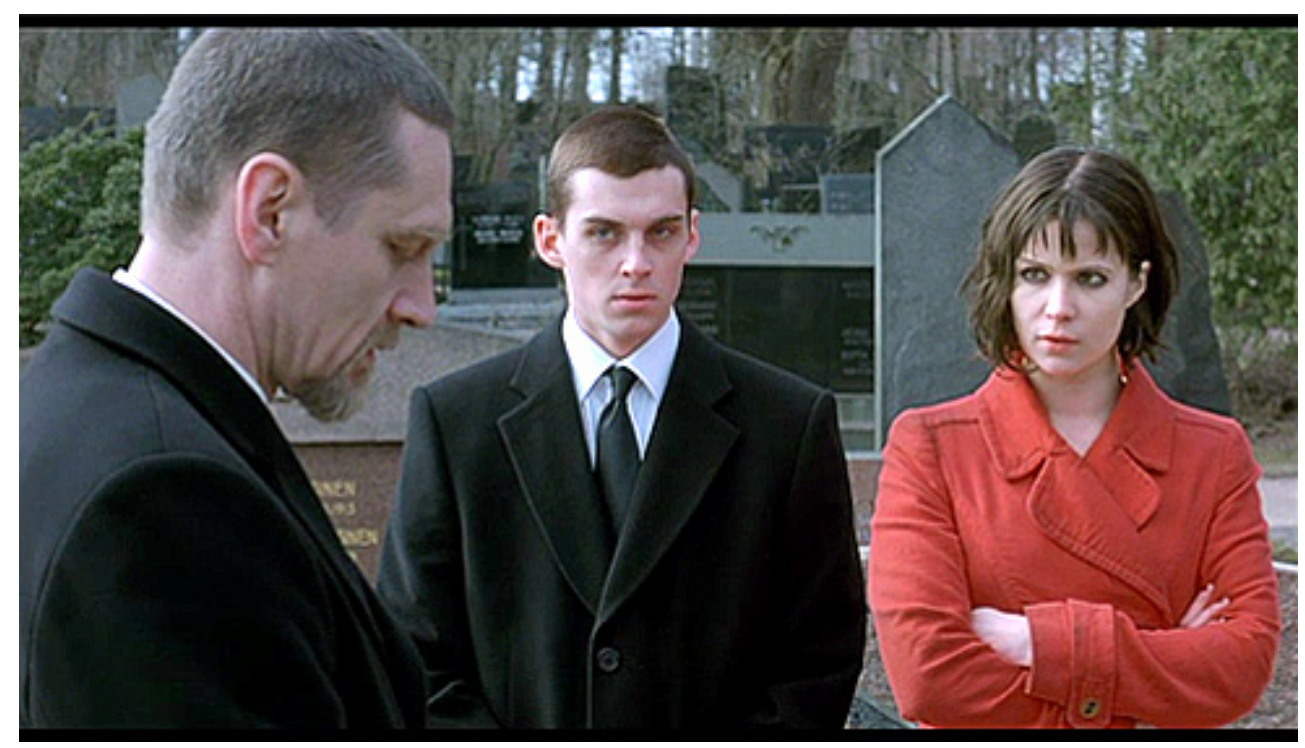

Kuva 6 (kuvakaappaus DVD:Itä). Paha perhe. Dani on valinnut puolensa.

Mikaelin aktiivinen menneisyyteen liittyvä ihmisjätehuolto tulee konkreettisesti sukupolvien ja luokkien välille, kun Dani ja Tilda katsovat perheen valokuva-albumia. Perhealbumi on performanssin väline, käsikirjoitettu toiston spektaakkeli, jossa perhe-elämän valituilla huippukohdilla rakennetaan ja osoitetaan kuulumista (Chambers 2001, 29). Perhealbumissa valokuvat toimivat halutun muistin proteesina, eli mukaan valitut ja ulos rajatut kuvat osoittavat sen, mikä halutaan unohtaa. Tildan valokuvaa Mikaelin albumeista ei löydy.

Tildan valokuvien puuttumisen syyn Mikael siirtää Tildan ja Danin äidille toteamalla: "Kyllä niitä otettiin. Oiskohan ne siinä muutossa johonkin hukkunu. Äitis ei ollut niitä kaikista järjestelmällisimpiä." Tildan ilmeestä Mikael huomaa tämän tietävän, että hän on pyyhkinyt elämästään pois kaikki tyttärensä jäljet. Tildan läsnäolo tekee Mikaelin epämiellyttävän tietoiseksi kuulumisen prosessuaalisuudesta, omasta kuulumisen sääntelystään sekä siitä, että hän ja hänen oma maailmansakin on hallitsematon (vrt. Lähdesmäki et al. 2016, 237).

Kuvien jätteeksi luokittelemisen paljastumisen jälkeen, kun perhe on matkalla sukulaistapaamiseen, Mikael sanoo autossa Tildalle, tätä kuin menneisyyttään taustapeilistä katsoen: "Mä haluun, että sä tiedät, että sulla on perhe - jos sä sellasta tarvitset." Perheellä Mikael viittaa omaan normaaliksi määrittämäänsä keskiluokkaisuuteen, johon Tilda ei kuulu. Mikaelin repliikin vastakuvana näemme Tildan ilmeen, joka kertoo hänen tietävän, että Mikael valehtelee, kuten aiemmin perhealbumia katsoessa.

Myöhemmin, kun Mikael on jättänyt kaiken hienotunteisuuden syrjään, hän yrittää rahalla jätehuoltaa Tildan ulos perheestään hänelle "kuuluvalle" paikalle. Dani ja Tilda ovat siirtäneet salaa isänsä tililtä kolmekymmentätuhatta euroa lähteäkseen yhdessä Costa Ricaan. Mikael tarjoaa summaa Tildalle sen jälkeen, kun hänelle moraalisen paniikin syöttänyt Kari on Mikaelin palkkaaman etsivän kanssa järjestänyt Tildan ja Danin erilleen. Mikael ja Tilda käyvät kotona kahden kesken lyhyen keskustelun, joka korostaa Mikaelin aktiivista erontekoa hänen ja tyttärensä edustaman alemman luokan välillä. 
MIKAEL: Saat pitää ne kolkyt tuhatta. Maksat sillä terapias (tauko). Kun mä sanon mä oon pahoillani, mä en parempaan pysty. Hyvää yötä. (Nousee ja yrittää lähteä.) TILDA: (Istuu pöydän ääressä.) Isä, mikset sä koskaan vastannu mun puheluihin? MIKAEL: Mä en muista. Soitit sä usein?

TILDA: Aika usein.

MIKAEL: Sul on hyvä syy olla muhun todella pettyny. (Lähtee pois.)

Sen sijaan, että Mikael yrittäisi selittää käytöstään, hän näyttää olevansa kiinnostunut ihan muista asioista. Mikael kiinnittää kaksisuuntaisen keskustelun sijaan huomionsa viinin purskutteluun ja kurlaukseen. Näin hän korostaa Tildan olevan hänen ylemmän keskiluokan maailmassaan jätettä. Leikkaus yleiskuvasta lähikuvaan viiniä maistelevasta eliitistä merkitsee Mikaelin käytöksen tahdittomuuden. Se on myös konkreettinen osoitus tavasta, jolla elokuva luokkateknologiana tekee tilanteesta komediallisen. Kamera seuraa tilannetta ulkopuolisena mutta asettaa meidät eettisellä tasolla hämmentyneen Tildan asemaan. Siksi vastakkainasettelu kritisoi Mikaelin omaksumaa keskiluokkaisuuden menestyseetosta, jonka mukaan muista kannattaa välittää vain tavalla, joka vaikuttaa omaan menestymiseen ja sen ilmenemiseen.

Luokka-asema kytkeytyy sukupuoleen menneisyys-nykyisyys-jaon lisäksi sekä Tildan ulkoisten piirteiden että käytöksen osalta. Suomeen tultuaan Tilda on lähetystössä konsulin juttusilla, jolloin käy ilmi, että hänellä ja hänen äidillään ei ole ollut Tanskassa asuntoa. Ainakaan Tilda ei kerro osoitetta. Asunnottomuus osoittaa keskiluokkaisuuden ideaalin saavuttamattomuutta, kuluttajakansalaisena epäonnistumista ja siten, vallitsevassa järjestyksessä, liiallisuutta (ks. Lahikainen \& Järvinen 2012, 12). Tilda eroaa olemuksensa, voimakkaasti meikillä rajattujen silmiensä ja ei-huolitelluilta vaikuttavien hiustensa puolesta elokuvan muista henkilöistä. Vaikka Tildaa ei ehkä ulkonäön perusteella voi suoranaisesti kuvailla määreillä liiallinen ja vastenmielinen, jotka Beverley Skeggs (2004, 99-103) liittää työväenluokkaisen naisen stereotyyppiseen representaatioon, hänen käytöstään ne kuitenkin kuvaavat hyvin. Mikael kokee Tildan liialliseksi siksi, että hän edustaa sitä, minkä hän on rajannut ulos Danille määrittämästään normaalista, porvariston hillityn charmin maailmasta.

Erityisen uhkaavaksi Mikael kokee Tildan seksuaalisuuden. Dania suojaavassa järjestyksessään hän pelkää, että Tildan käytöksen liiallisuus ja yllyttävyys muuttavat Danin harkitsemattomaksi. Pelko muistuttaa Skeggsin (2004, 100) huomiosta, jonka mukaan työväenluokkaisen naisen seksuaalisuutta on representoitu uhkana koko läntiselle sivilisaatiolle. Sukupuoleen liitetyn liiallisuuden merkitys jätehuolletun menneisyyden ja normitettua keskiluokkaisuutta uhkaavan käytöksen merkitsijänä korostuu kohtauksessa, jossa Mikael koputtaa oveen Danin ja Tildan polttaessa huoneessa marihuanaa. Mikael repii Danin sängystä ja raahaa hänet vaatteet päällä suihkuun.

Vettä valuvan suihkun alla Mikael lyö avokämmenellä Dania poskelle ja saa yhden iskun takaisin. Hän korottaa ääntään ja nimittelee poikaansa: "Saatanan aasi! Mikä suhun on menny? Kuvittelet sä yhtäkkiä voivas tehdä iha mitä vaan?" (kuva 7). Dani on astunut Mikaelin rajaaman hillityn keskiluokkaisen - ja marihuanan polttamisellaan lainmukaisen - käytöskoodiston ulkopuolelle. Poika ei ole enää isän kontrollissa, mitä osoittaa konkreettisena jälkenä tatuointi. Se on kuin toisen luokan merkki, jonka Mikael näkee revittyään Danilta paidan päältä (kuva 8). Mikael pitää syynä ainoastaan Tildan liiallisen käytöksen vaikutusta. "Et sä nää, mitä se tekee sulle", Mikael kysyy ja harppoo Tildan luokse. 

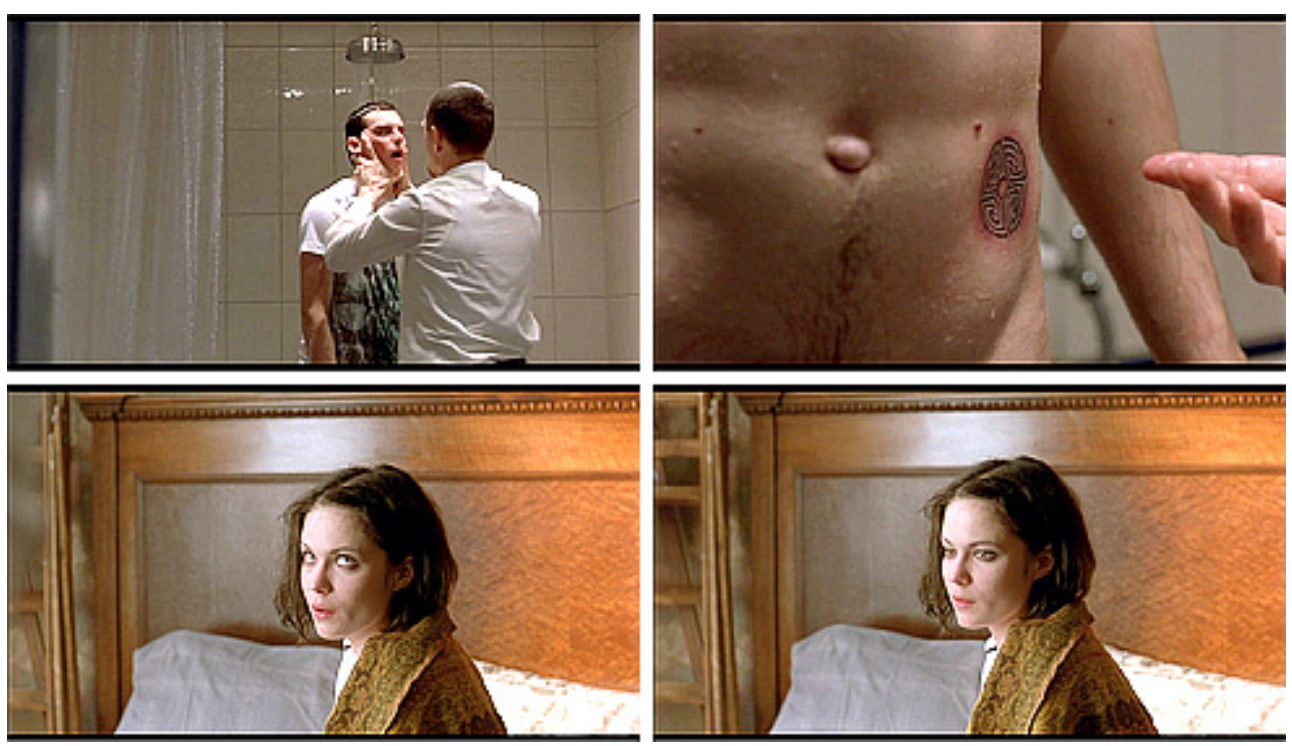

Kuvat 7-10 (kuvakaappaukset DVD:Itä). Paha perhe. "Dani on mun poika."

Mikaelin puhuessa Tildan puolilähikuvassa nähtävien, Mikaelia ylöspäin katsovien kasvojen ilmeen muutos kertoo, miltä tuntuu tulla jälleen sysätyksi syrjään (kuvat 9 ja 10). Mikael toteaa: "Sun ei tarvii opettaa sille kaikkia temppujas. Dani on mun poika." Sanavalinnallaan Mikael rajaa Tildan perheen ulkopuolelle. Tokaisunsa jälkeen hän lähtee välittömästi pois huoneesta antamatta Tildalle mahdollisuutta sanoa mitään. Toisaalta Mikael mitätöi tyttärensä olemassaolon niin tylysti, että kenties Tilda ei olisi edes saanut mitään sanottua. Mikaelin aktiivisen jätehuollon tylyyttä korostaa suora leikkaus Tildan suruun kääntyneestä ilmeestä teepöytään, jossa Mikael käyttäytyy kuin mitään ei olisi tapahtunut. Mikaelin ihmisjätehuollossa kuitenkin työ ja koti sotkeutuvat toisiinsa, mikä saa hänet vähitellen ymmärtämään sen, että hänen oma toimintansa saattaisi olla liiallista ja väärää.

\section{Epäonnistumisista itsen jätehuoltamiseen}

Sukupolvien välisessä konfliktissa kompromisseihin taipumaton Mikael on etsinyt yhteyttä poikaansa vain oman käsikirjoituksensa ehdoilla. Koska Mikael kokee Danin uhkaavan jatkuvuuden katkeamisella, hän päätyy lopulta toimimaan lainvastaisesti. Mikaelin ihmisjätehuolto on esimerkki siitä, miten uusliberalistisen menestyseetoksen pakonomainen ylläpito voi johtaa yksinäisyyteen. Verhaeghen $(2014,205-206)$ mukaan yksinäisyys on merkittävimpiä uusliberalismin yksilöiden välisen kilpailun tuottamia ongelmia. Mikaelin nähdäänkin elokuvassa monesti jäävän yksinäiseksi erityisesti silloin, kun hän on joutunut puolustamaan suojelemaansa järjestystä.

Hyvä esimerkki yksin jäämisestä on kohtaus, jossa lastensa suhteen luonnetta epäilevä Mikael hakee yllättäen Danin koulusta kesken oppitunnin ja vie hänet satama-alueelle, jossa hänen on aiemmin nähty opettavan Danille autolla ajamista. Sataman kylmässä, tuulisessa välitilassa isä ja poika seisovat vieretysten ja katsovat merelle. Mikael puhuu pojalleen viittaamalla normaaliuteen, epäonnistuu ja jää yksin yritettyään selittää, miksi hän ei hyväksy sitä, että Dani ja Tilda nukkuvat samassa huoneessa. 
MIKAEL: Se on epänormaalia Dani.

DANI: Siin ei oo mitään pahaa.

MIKAEL: Älä viitti. Sä et ole noin yksinkertane.

DANI: Mä en haluu puhuu tästä, sä et tajuu. (Kääntyy pois.)

MIKAEL: (Ottaa Dania olkapäästä kiinni.) Nimenomaan tajuun ja sen on loputtava. Mitä hyvänsä se onkin. Ei mun jumalauta tarvii edes tietää. Kuuntele meitä nyt.

Onks tää sun mielestä normaali keskustelu?

DANI: No me ei nussita, jos se on se paise tässä!

MIKAEL: (Hermostuu silmin nähden.) Ai jaa, olette pitäytyneet (tauko) perinteisestä yhdynnästä. Hieno homma.

DANI: Vittu sä oot sekasin.

MIKAEL: Äläkä sitä paitsi valehtele mulle. Mä oon kuullu ääniä.

DANI: Siihen on lääkkeet.

Mikael viittaa keskustelun aikana kahdesti normaaliuteen ja Dani viimeisillä repliikeillään Mikaelin mielikuvitukseen ja ajattelun irrationaalisuuteen. Mikael epäonnistuu keskustelussa mutta ei anna periksi. Kuten hän elokuvan alussa Danille totesi: "Jos antaa periks periksantamiselle, ei enää muuhun pystykään." Mikaelin periksiantamattomuus kuitenkin johtaa yksin jäämisen (kuva 17) lisäksi siihen, että työ alkaa selvästi vaikuttaa kodin tapahtumiin ja kodin tapahtumiin liittyvä vilkas mielikuvitus tuomarintyöhön. Lopulta Mikael yrittää suojella päänsä sisälle rakentuneen maailman järjestystä rikkomalla lakia. Tapahtumasarja muistuttaa Mikaelin ja Milon elokuvan alussa käymää keskustelua siitä, onko Mikael joskus tuominnut syyttömän vankilaan.

Mikael ostaa pienen videokameran, jota hän tarkastelee oikeussalissa kesken käsiteltävänä olevan oikeusjutun todistajalausuntojen. Milon kanssa käyty keskustelu asettuu uuteen valoon, sillä Mikael ei keskity kuuntelemaan todistajalausuntoja mutta julistaa silti tuomion. Kotona Mikael piilottaa videokameran hyllyyn huoneessa, jossa Dani ja Tilda nukkuvat. Nuoret kuitenkin löytävät kameran hyllystä ennen nukahtamista.

Aamulla Mikael hakee hyllyyn piilottamansa kameran. Hän avaa sen pelokkaana mutta joutuu taas toteamaan epäonnistuneensa: kameran löytäneet

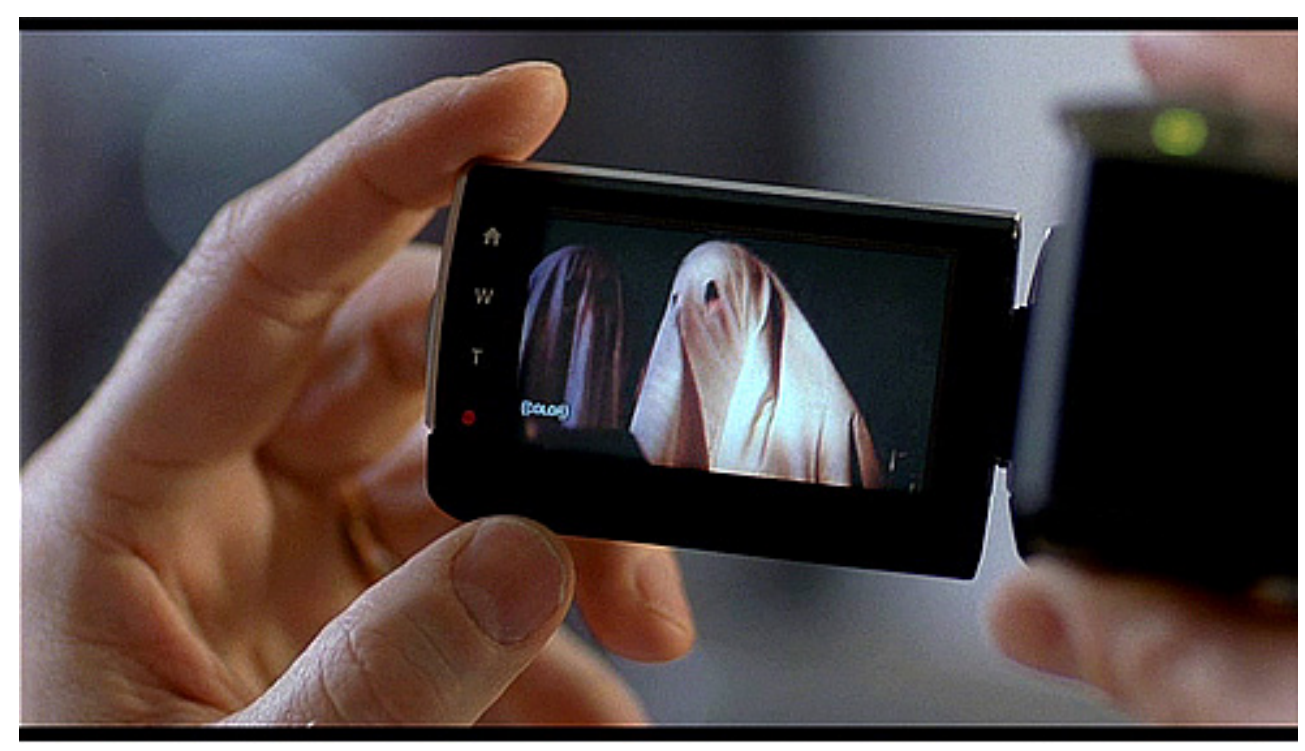

Kuva 11 (kuvakaappaus DVD:Itä). Paha perhe. Nöyryytys. 
Dani ja Tilda ovat pilailleet isänsä kustannuksella piiloutumalla lakanan alle ja esittämällä ulisevia haamuja. Kohtauksessa, jossa salakuvauksen yritys paljastuu, jännityksen laukaisee huumorin tuottama genreristeys. Se kutsuu meidät nauramaan Mikaelin älyttömälle toiminnalle. Epäonnistumisen paljastuminen näytetään lähikuvassa Mikaelin subjektiivisena katseena videokameran pieneen näyttöön (kuva 11). Epäonnistuminen nöyryyttää Mikaelia etenkin siksi, että Dani ja Tilda ovat pitäneet häntä pilkkanaan.

Luokkateknologiana elokuva osoittaa Mikaelin tekevän käyttäytymisellään itsestään perheensä toisen, periksiantamattomuudessaan yksinäisen ja poikkeavan, jonka muut huomaavat tarvitsevan apua. Ensin Dani toteaa humoristisesti mutta ainakin osin tosissaan isänsä kuulemiin ääniin, että "siihen on lääkkeet". Lääkkeistä puhuminen muistuttaa Verhaeghen (2014, 33-34, 206) korostamaa ympäristön vaikutusta käytökseemme, toimintatapoihimme ja identiteettiimme. Vallitseva järjestys ei itse tätä käsittele, sillä uusliberalistinen ajattelutapa ei tunnu välittävän tuottamistaan vaikutuksista vaan keskittyy Mikaelin tapaan ainoastaan itseään häiritsevään erilaisuuteen, jonka järjestys leimaa epänormaaliksi. Tällaisena elokuvassa näyttäytyy sisarusten nukkuminen samassa huoneessa.

Mikaelin ongelmista mainitsee myös Laura, jonka Mikael on jätehuoltanut Milon kanssa hotelliin. Heidän piti viettää hotellissa yksi yö, mutta he ovatkin hotellissa, poissa Mikaelin tieltä, useita öitä. Kun Mikael käy katsomassa heitä, hän syyttää Lauraa siitä, että tämä on jättänyt Milon yksin hotellihuoneeseen. Hän tulee kuitenkin korostaneeksi oireellisesti itse, että kyse on nimenomaan hänen päässään tapahtuvasta liikkeestä. ${ }^{7}$

LAURA: Ai, minäkö se tässä se outo oon? Auta mua sitten. Kerro mulle, mitä sun päässä liikkuu.

MIKAEL: Dani ja Tilda nai toisiaan. Mun päässä liikkuu et se ei oo hyvä. Mun päässä liikkuu et sen pitää loppua. Mun päässää liikkuu et mun pitää se lopettaa.

Hotellissa käydystä, väittelyksi ja huutamiseksi kehittyneestä keskustelusta siirrytään kotiin, jossa hoitaja on leikkaamassa Mikaelin isän hiuksia. Mikael tempoo viereisessä huoneessa soutulaitettaan, kunnes kuin yhtäkkisestä päähänpistosta nousee, astelee hoitajan luo ja toteaa: "Pakataas papan tavarat. No niin saman tien (tauko). Pääset vähän tuulettuu." Vaikka Mikaelin isä on kotonakin ikänsä ja sairautensa vuoksi perheen ulkopuolinen (ks. Varjakoski 2015, 69), Mikael jätehuoltaa hänet järjestykselleen ylimääräisenä ja taakkana hoitokotiin. Pyörätuolissa istuvan, puhekyvyttömän isänsä perheestä ulosrajaaminen muistuttaa konkreettisesti uusliberalistista, talouteen perustuvaa jätehuoltoa, joka aina myös määrittelee oikeanlaista ihmisyyttä.

Isänsä perheestä ulos rajaamisestakin Mikael syyttää Tildaa, jolle hän toteaa: "Mä toimitin Papan hetkeks muualle. Ei senkään tarvitse kaikkee katsella." Syytöksen hetkellä, viinilasin äärellä, vanhemman ja lapsen hierarkkisen suhteen mielivaltaisuus näyttäytyy äärimmilleen vietynä, kun Mikaelin ja Tildan keskustelun kanssa leikataan ristiin tapahtumia saaresta, johon Kari on Mikaelin pyynnöstä Danin muiluttanut. Vapaudenriiston kohteeksi joutunut Dani käy Karin kimppuun ja vaatii saada puhelimensa. Kari kieltäytyy, painaa Danin pään lattiaan ja sanoo elokuvan sukupolvikonfliktin ja uusliberalistisen eetoksen avainlauseen: "Tää on kaikki ihan sun parhaaks."

Toteamus ulottuu myös Tildaan, sillä Mikaelin ja Karin mielessä sisarusten läheisyys ei ole normaalia. Tilda suutelee sisarellisesti Dania kerran, mutta koska emme näe mitään, mikä saisi päättelemään heidän suhteensa olevan
7 Pahan perheen arvosteluissa sisarusten välinen seksuaalinen suhde ymmärrettiin pääasiassa Mikaelin mielikuvituksen tuotteeksi. Esimerkiksi Turun Sanomien arvostelussa (Topelius 2010) todetaan: "Salmenperän tarinoissa miesten pahin virhe on heidän jättäytymisensä yksin, mikä johtaa heidät kiertämään tuloksetonta kehää omien ajatustensa ympärillä." Poikkeus on Karjalaisen arvostelu (Vaarala 2010), jonka otsikossa jo kysyttiin: "Voiko insestin kieltävä isä olla 'ylisuojeleva'?" 
seksuaalinen, elokuva kyseenalaistaa sen, että sukupolvikonfliktissa vanhempi aina tietäisi, mikä on aikuisuuden kynnyksellä olevalle lapselle parhaaksi. Näin elokuva kyseenalaistaa luokkateknologiana myös pakottavan jatkuvuuden mallin, jota valta-asemassa oleva yrittää ihmisjätehuoltotoimin pitää yllä.

Karin toteamus liittyy sukupolvikonfliktiin, mutta Tildan kohdalla sitä voi selittää myös Mikaelin omaksumalla köyhyyden kulttuurin teesillä (culture of poverty). Teesi vapauttaa uusliberalistisen keskiluokan vastuusta, sillä sen mukaan epäonnistuminen on yksilön sukupolvelta toiselle siirtyvä moraalinen ongelma, joka estää menestyksen esimerkiksi työssä ja koulussa (ks. esim. Bulman 2013, 73; Gandal 2007, 4). Epäonnistumisen syyksi selitetään siis väärät arvot ja asenteet niin työntekoa, koulua kuin perhettäkin kohtaan. Tässä epäilyttävässä, pakottavassa näkemyksessä, jossa köyhyyttä pidetään ansaittuna (esim. Evans \& Giroux 2015, 4), ihminen tuomitaan, koska häntä ei nähdä kykeneväksi omaksumaan valtajärjestyksen normina pitämiä keskiluokkaisia hyveitä. ${ }^{8}$ Siksi Mikael toimii poikkeuksellisesti poikaansa kohtaan ja haluaa päästä eroon tyttärestään - ja siksi elokuva esittää keskiluokkaisen maskuliinisuuden kriisiytyneenä, ideaaliasemansa menettäneenä niin, että epäonnistuneisuus, jota yritetään karttaa, esitetään lopulta pysyvänä tilana (ks. Chambers 2001, 109).

Helsingin Sanomien arvostelussa (Avola 2010) todetaan elokuvan näyttävän "draaman keinoin, että tällainen miehen malli ei enää toimi, että maailma on ajanut lopullisesti sen ohi." Kriisiin ovat ajaneet kaikille elämän alueille, perheeseenkin, ulottuva uusliberalistinen menestyksen vaatimus, joka on kolonisoinut Mikaelin tajunnan. Luokkateknologiana elokuva korostaa tätä vakavissa, koomisilta tuntuvissa tilanteissa, joissa katsoja asemoidaan menestystä ylläpitämään pyrkivän epäilijäksi. Kun Mikael päättää jäädä tuomarin työstään virkavapaalle kyetäkseen kotona tiukempaan kontrolliin, hän yrittää työyhteisölleen peitellä epäonnistumistaan valehtelemalla:

Kaikki asiat on hyvin. Aion jäädä puolen vuoden virkavapaalle, ja jotta teidän ei tarvitsis spekuloida täällä syytä niin kerronkin (tauko) aion ryhtyä koti-isäks. Vanhempi poika on viimeistä vuotta koulussa ja (pitkä tauko) kirjoittaa. Nuorempi on juuri päässyt ensimmäisen vuotensa loppuun ja (tauko) että tähän ei tosiaan liity sen kummempaa dramatiikkaa että pitää vaan tarkistaa vähän, kaikki siis on hyvin, pitää vaan tarkistaa, että voisko joku asia olla vähän paremmin.

Mikaelin pöydän päästä tarjoaman selityksen (kuva 12) aikana hänet nähdään puolikuvassa työkavereiden päiden välistä (kuva 13). Näin meidät asemoidaan katsojina kuulemaan selitystä, jonka tiedämme valheeksi. Mikaelin puheen tauot implikoivat, että hänen on vaikea esittää asiaansa, ja tämä tuottaa tilanteeseen miltei vahingoniloista komiikkaa. Menestyksen vaatimus pakottaa Mikaelin valehtelemaan, mihin hän ei hallitusti työkavereidensa edessä pysty. Kun Mikael pitää Danin mainittuaan puheessaan pitkän tauon, näemme vastakuvassa pöydän ympärillä olevat kuulijat, joiden vaivaantuneet, sivulle hakeutuvat ja alaspäin painuvat katseet kertovat heidänkin tietävän, että Mikael ei puhu totta (kuva 14).

Virkavapaallaan Mikael jätehuoltaa itsensä ulos hovioikeudesta, yhteiskuntaa ylläpitävästä järjestelmästä, jonka harkitseva osa hän ei enää kodin tapahtumien vuoksi pysty olemaan. Tämä ei kuitenkaan estä häntä tarttumasta lakikirjaan kotona, jossa työ jatkuu. Pahassa perheessä kuulumisen jatkuva mukaan ottamisen ja ulosrajaamisen prosessi kytkeytyykin oleellisesti juuri Mikaelin ammattiin, joka limittää perheen ja yhteiskunnan tason konkreet-
8 Tätä seuraten voi todeta, että uusliberalistisen luokkajärjestyksen perustava erhe on uskomus siitä, että kun riittävästi yrittää, jokainen voi menestyä. Ja kun menestystä tulee, se on jokaisen oma ansio. Toisaalta silloin, kun ajatellaan, että kaikki ovat oman onnensa seppiä, väitetään samassa jokaisen olevan itse syypää, jos elämässä ei tule menestystä. 

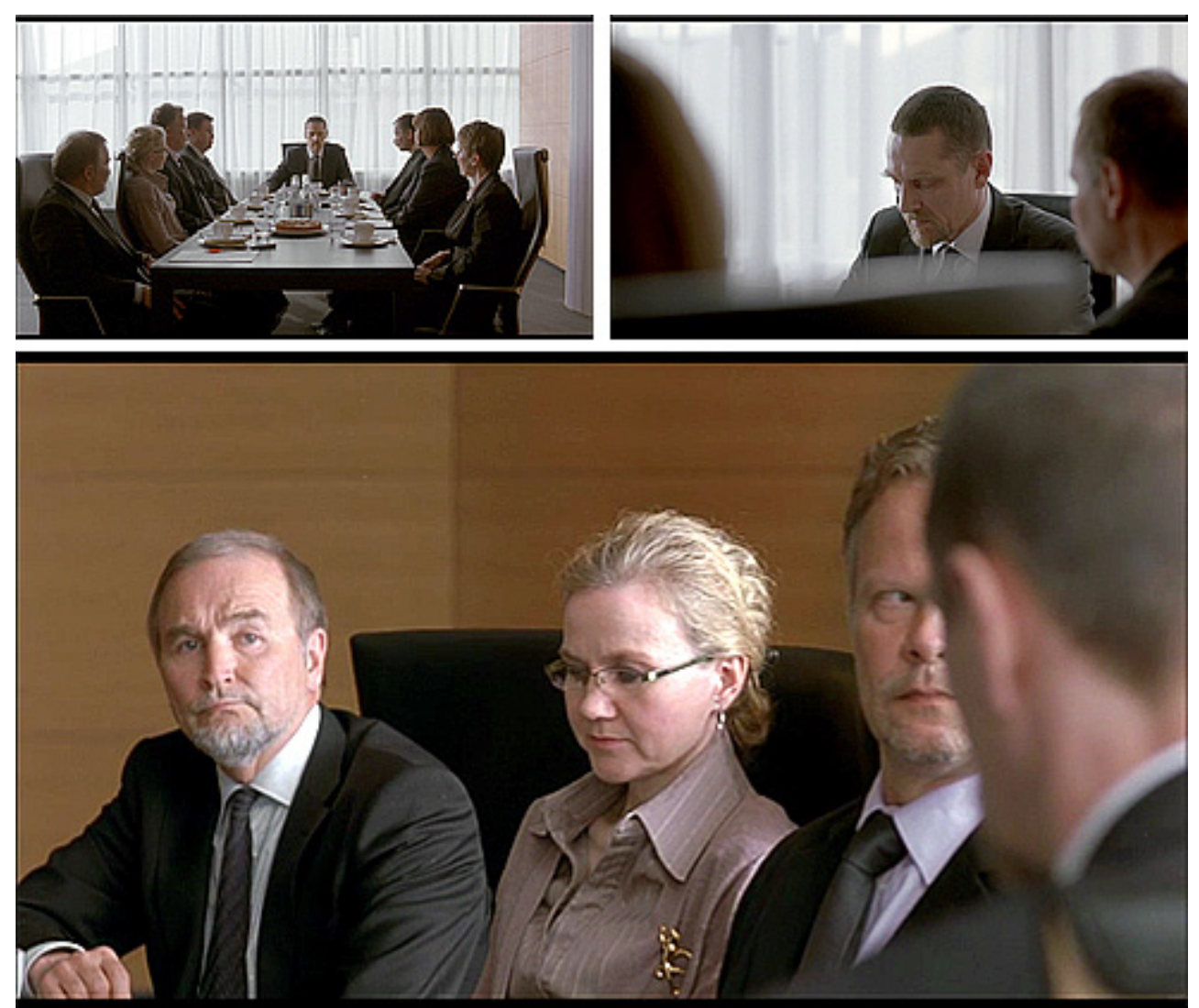

Kuvat 12-14 (kuvakaappaukset DVD:Itä). Paha perhe. "Kaikki on hyvin."

tisesti toisiinsa. Tuomarin työ on yhteiskunnallista ihmisjätehuoltoa, yhteiskuntaan kuulumisen rajojen osoittamista tavalla, jossa lainrikkojat suljetaan yhteiskunnan ulkopuolelle.

Lain ja kodin yhteys konkretisoituu kohtauksessa, jonka alussa Mikael asettaa vinyylisoittimesta soimaan kevyttä puhallinjatsia ja istuutuu sohvalle lukemaan romaania. Mikaelin toimet näyttäytyvät performanssina ylemmän keskiluokan hillitystä, korkeakulttuurista saatavasta nautinnosta (vrt. Bourdieu 1984, 77). ${ }^{9}$ Mikael naurahtaa lukemalleen väkinäisesti ja tarkkailee samassa läheisen pöydän ääressä juttelevaa Tildaa ja Dania, jotka tutkiskelevat kämmentensä viivoja. Kuulemme Tildan sanat "saat kaks lasta", joista Mikael ärsyyntyy silmin nähden. Kun nuoret nousevat ja lähtevät nukkumaan, hän yrittää saada Danin nukkumaan omaan huoneeseensa siinä onnistumatta. Danin ja Tildan suljettua huoneensa oven Mikael hakee kirjahyllystä lakikirjan, kävelee lukossa olevalle ovelle ja lukee kovaan ääneen ärtyneenä:

Rikoslaki 17, pyk - - luku 22. Sukupuoliyhteys lähisukulaisten kesken. Joka on sukupuoliyhteydessä oman lapsensa tai tämän jälkeläisten kanssa, oman vanhempansa tai tämän vanhemman, taikka veljensä TAI SISARENSA KANSSA (ääntään entisestään korottaen), on tuomittava sukupuoliyhteydestä lähisukulaisten kesken sakkoon tai vankeuteen, kahdeksi vuodeksi vankeuteen. Haluutteks te saatanan apinat et mä teen rikosilmotuksen?

Mikael lukee lakikirjaa ääneen käytävässä, jossa hänet kuvataan elokuvassa monta kertaa subjektiivisella otoksella kävelemässä kohti Danin ja Tildan huo-
9 Aamulehden arvostelussa Antti Selkokari (2010) kirjoittaa uusliberalistiselle otteelle kuvaavasti: "Perheen koti on pimeä lukaali, jossa levylautasella pyörivät alinomaa Chopinin preludit ja Brahmsin intermezzot. Ei siksi, että musiikista välitettäisiin, vaan siksi, että se on osa statukseen kuuluvaa sisustusta, kuten tottelevainen vaimo ja lapsetkin." 

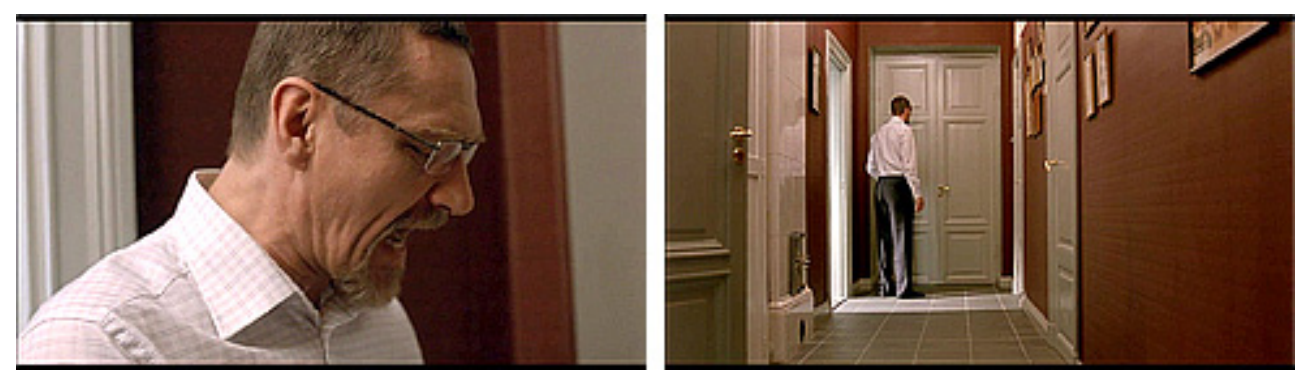

Kuvat 15 ja 16 (kuvakaappaukset DVD:Itä). Paha perhe. "Saatanan apinat - -."

neen ovea tai katsomassa oven suuntaan. Käytävä on Mikaelin hallussa, mutta siitä on tullut hänelle vankila tai päänsisäisen järjestyksen ahdas labyrintti, jossa kaikki on niin kuin hän haluaa mutta jonka yksinäisyyteen hän myös tulee toimillaan itsensä sulkeneeksi. Ammattiaseman ottaminen ja lakikirjan siteeraaminen omille lapsille näyttäytyy huvittavana siksikin, että Dani ja Tilda ovat lähteneet huoneesta pois sillä aikaa, kun Mikael on tuskissaan etsinyt lakikirjasta haluamaansa kohtaa. Hän siis jyrisee lakia yksinäisyydessään tyhjälle huoneelle (kuvat 15 ja 16).

Mikael lukee tuomarina lakia lapsilleen, joista on tullut hänelle samanlainen projekti kuin työssä käsiteltävistä oikeusjutuista. Työ ja koti sotkeutuvat toisiinsa, mutta samassa sotkeutuu Mikaelin oikeudentaju. Ymmärtämättömyys ja periksiantamattomuus johtavat siihen, että lopulta hän riistää pojaltaan vapauden.

Kun Mikael näkee Danin Karin autossa tainnutettuna, hän ymmärtää tehneensä väärin, kenties tuominneensa poikansa vailla varmuutta väärin perustein, minkä mahdollisuudesta kuulimme Milon kysyvän jo elokuvan alussa. Auton vietyä Danin näemme Mikaelin jäävän yksin seisomaan keskelle tietä (kuva 18). Menestyksen pinnan ylläpitoon ja epäonnistumisten piilottamiseen tähtäävä ihmisjätehuolto johtaa koko ajan laajenevaan yksinäisyyteen, mikä tuskin oli Mikaelin tarkoitus.

\section{Ulos yksinäisyydestä?}

Paha perhe kuvaa perhettä pienoiskokoisena yhteiskuntana, jossa käydään neuvottelua siitä, millä ehdoin perheeseen voi kuulua ja mitä siitä seuraa, jos ei käyttäydy odotetulla tavalla. Perheen hierarkiassa keskeisenä määrittäjänä näyttäytyvät ylemmän keskiluokan perheen isän vaalimat arvot, joiden noudattamisen tulisi näkyä menestykseen liittyvänä hillittynä käytöksenä. Arvot, jotka johtavat isän ja pojan syvenevään sukupolvikonfliktiin, ovat pinnan merkitys, yritteliäisyys ja periksiantamattomuus sekä niistä seuraamaan ajateltu menestyminen ja sen parina epäonnistumisen kieltäminen. Näiden toteutumista omalla kohdallaan perheen isä kontrolloi jääräpäisesti vailla kykyä tai halua kompromisseihin.

Perheessä valtaa pitävän keskeinen hallinnan keino on ihmisjätehuolto, vaadittuun tai oletettuun järjestykseen kuulumattomien henkilöiden sulkeminen perheyhteisön ulkopuolelle. Tähän viittaa myös artikkelin otsikko "tää on kaikki ihan sun parhaaks", jonka mukaan joku muu tietää ja päättää, mikä kenellekin on parasta. Konfliktissa valta kuvittelee aina tietävänsä sen, 
mikä on kenellekin parhaaksi. Oman menestyksensä kuorta ylläpitävä Mikael toimii kuin yksiselitteiseksi rakennettu pääomaelokuva, jossa ideologisesti oikeamielinen henkilö etenee päämäärätietoisesti kohti ongelman ratkaisua rajaamalla ristiriidat itsensä ulkopuolelle. Paha perhe kuitenkin tekee Mikaelin jätehuoltotoimet niin selväksi ja naurettavaksi, että se tulee haastaneeksi myös pääomaelokuvan perustaa.

Paha perhe käy sukupolvikonfliktin kehyksessä neuvottelua uusliberalistisen eetoksen läpäisemän yhteiskunnan kilpailua ja menestystä ylimpänä mittanaan pitämistä arvoista ja niiden noudattamisen seurauksista. Uusliberalismin ihanneyksilö, joka välittää vain omasta menestyksestään, ilmestyi suomalaiseen elokuvaan heti 1990-luvun lopussa käynnistyneen suomalaisen elokuvan buumin alkutahtien jälkeen vuoden 2000 alun Levottomissa (ensiilta 28.1.2000). Siinä lääkärinä työskentelevän nousukkaan keskiluokkaisen päähenkilömiehen ihmissuhteet näyttäytyvät vaihto- ja tavarasuhteina, joiden päämääränä on oma mielihyvä muista välittämättä.

Paha perhe on yksi kertomus siitä, miten 2000-luvun uusliberalistisen politiikan ja eetoksen painossa luokkajakoja pidetään yllä. Kuulumista muuttoliikkeiden ja maahanmuuttajuuden näkökulmasta paljon tarkastellut Floya Anthias $(2006,17)$ pitää sijoiltaan olemista ja sitä seuraavaa syrjäyttämistä keskeisenä nykymaailmaa määrittävänä piirteenä. Paha perhe kuvaa tätä syrjäyttämistä yhteiskunnan mikrotasolla. Siinä perheeseen kuulumista määrittävä ja ulos rajaava toiminta ovat vallan näkökulmasta oikeanlaisen perheeseen kuulumisen ehtojen ylläpitoa. Luokkateknologiana Paha perhe kuitenkin, erityisesti komediaan taipuvissa genreristeyksissä, pyytää katsojaa kyseenalaistamaan isän ehdottomuuden. Näin se osoittaa sekä elokuvan tekemiseen liittyvän valinnan että vaihtoehtoisten maailmojen mahdollisuuden.

Perheiden ja sukupolvikonfliktin kautta uusliberalistista eetosta kuvataan ja kommentoidaan selvimmin 2010-luvulle tultaessa. Pahan perheen tapaan tästä hyvä esimerkki on Roskisprinssi (2011), jossa ylioppilaaksi päässeen keskiluokkaisen perheen pojan tulevaisuusodotukset ovat ristiriidassa isän asettamien menestysodotusten kanssa. Tämä ajaa pojan irtaantumaan perheestään. (Ks. Römpötti 2012.) Tällaisissa elokuvissa neuvotellaan kuulumisen ehdoista samoin kuin Pahassa perheessä, joskin niin, että nuori lähtee vapaaehtoisesti pois isänsä vaatimasta järjestyksestä, jota hän ei koe omakseen. Sukupolvikonflikti on kuulumisen neuvottelun aiheena merkittävä, sillä kuuluminen ja ulosrajaava vallankäytön jätehuolto tulevat selvimmin esiin suhteessa alisteisessa asemassa oleviin, esimerkiksi lapsiin ja nuoriin (esim. Lähdesmäki et al. 2016, 240).

Pahan perheen lopussa Mikael yrittää höllentää uhkaan perustuvaa luokkajärjestystään ja siitä seurannutta yksinäisyyttään viemällä Danin Tildan luokse. Mikaelin käyttäytymisen absurdius korostuu, kun hän poikaansa kohdistamien laittomuuksien jälkeen yrittää vielä siirtyä isän ohjaavaan rooliin: "Osaisinkohan mä nyt antaa sulle jotain isällisiä ohjeita (tauko) Älä koskaan - - Muista aina - -". Keskusteluyrityksen epäonnistuminen osoittaa, että Mikaelin aiempi auktoriteettiasema on murtunut. Hän on jäänyt kyvyttömyyden tilaan, jossa hän ei saa sanottua lauseita loppuun. Perhe on hajonnut ja valta muuttunut toimintahäiriöiseksi. Viemällä Danin Tildan luokse Mikael tulee itsekin tunnustaneeksi luokkajärjestyksensä ongelmallisuuden. Elokuva antaa kuitenkin lopuksi Mikaelille vielä yhden mahdollisuuden päästä eroon yksinäisyydestä.

Mikael ajaa ohi levähdyspaikan, jossa on mies vaihtamassa autoonsa renkaita. Hän jarruttaa äkisti ja peruuttaa levähdyspaikalle, astuu ulos autostaan 
ja ryhtyy auttamaan, vaikka mies sanoo pärjäävänsä yksin. Yhtäkkiä Mikaelilla on tarve auttaa vierasta ihmistä. Hänen tarpeensa on kuitenkin pakottava, jolloin yhteyttä ei synny. Tätä osoittaa myös se, että Mikael alkaa kertoa vieraalle ihmiselle aikomuksestaan ostaa pojalleen joku "autonkottero niinku mun isä hommas mulle". Vieraan edessä hän pitää edelleen yllä jatkuvuutta. Mikael kättelee miestä pakonomaisesti kaksin käsin ja toivottaa kaikkea hyvää. Mies pudistaa päätään ja huristaa tiehensä heti, kun se on mahdollista. Mikaelia voisi luulla psykopaatiksi, joka voi tehdä mitä tahansa. Hän jääkin lopulta yksin, kuten monesti aiemminkin pakottavissa toimissaan (kuvat 17-19).
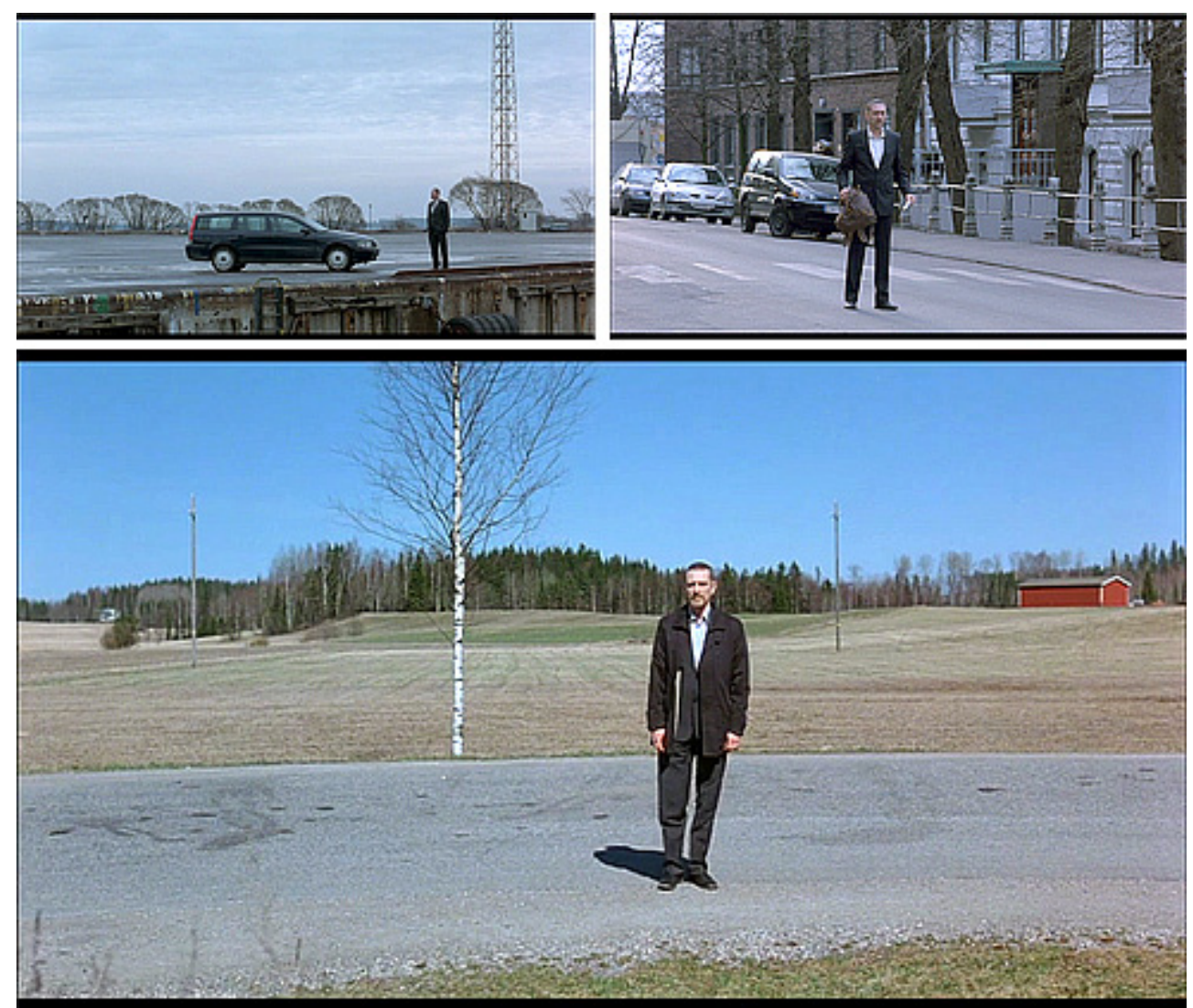

Kuvat 17-19 (kuvakaappaukset DVD:Itä). Paha perhe. Yksin satamassa, kadulla ja levähdyspaikalla.

Luokkateknologiana Pahan perheen voi ajatella ottavan lopuksi konkreettisesti kantaa myös uusliberalismin tuottamaan yksinäisyyteen: elokuva jättää Mikaelin yksin, koska häntä ohjaa pakottava malli. Hänen periksiantamattomuutensa ei näyttäydy keskiluokkaisuuteen liittyvänä hyveenä vaan tukahduttavana periaatteena, joka pyrkii sulkemaan ulkopuolelleen kaiken, mikä ei sen raameihin sopeudu.

Olen esittänyt yhden tavan, jolla Paha perhe ehdottaa luokkajakoa pidettävän yllä nykyaikana ja jolla se kyseenalaistaa tuon ylläpidon. Kyseenalaistamista korostaa kerronnan tasolla vielä elokuvan päättävä yleiskuva (kuva 19). Siinä Mikael seisoo yksin levähdyspaikalla avoimessa, tuulisessa maisemassa ja katsoo kameraan. Kun elokuva kääntää katseensa Mikaelin silmin katsojaan ja työntyy rajojensa yli, se yhdistää fiktion ja arjen ja pyytää, että 
se tulisi ymmärtää suhteessa elokuvan ulkopuoliseen maailmaan. Paha perhe vastustaa menestystarinan ehdottomuutta, sillä se ei pakota Mikaeliakaan määrittämiinsä raameihin vaan luokkateknologiana pikemminkin pakottaa meidät ottamaan noihin raameihin kantaa.

\section{Lähteet}

Anthias, Floya (2006) "Belongings in a Globalising and Unequal World: Rethinking Translocations". Teoksessa Nira Yuval-Davis, Kalbana Kannabiran \& Ulrike Vieten (toim.) The Situated Politics of Belonging. Lontoo: Sage, 17-33.

Avola, Pertti (2010) "Kunnian mies kompastuu". Helsingin Sanomat NYT 29.10.2010.

Bauman, Zygmunt (2004) Wasted Lives: Modernity and its Outcasts. Cambridge: Polity Press.

Bell, Vikki (1999) "Performativity and Belonging. An Introduction". Theory, Culture E Society vol. 16:2,1-10.

Beller, Jonathan (2006) The Cinematic Mode of Production. Attention Economy and the Society of the Spectacle. Hanover \& New Hampshire: Dartmouth College Press.

Bourdieu, Pierre (2013) "Symbolinen pääoma ja yhteiskuntaluokat". Suom. Urpo Kovala. Sosiologia 2.

Bourdieu, Pierre (1985 [1984]) Sosiologian kysymyksiä. Suom. J. P. Roos. Tampere: Vastapaino.

Bourdieu, Pierre (1984 [1979]) Distinction. A Social Critique of the Judgement of Taste. Cambridge \& Massachusetts: Harvard University Press.

Chambers, Deborah (2001) Representing the Family. Lontoo: Sage.

Dave, Paul (2007) Visions of England. Class and Culture in Contemporary Cinema. Oxford \& New York: Berg.

De Lauretis, Teresa (1980) "Through the Looking-Glass". Teoksessa Teresa De Lauretis \& Stephen Heath (toim.) The Cinematic Apparatus. London: Macmillan Press, 187-202.

De Lauretis, Teresa (1987) The Technologies of Gender. Essays in Theory, Film, and Fiction. Bloomington: Indiana University Press.

Dimmock, Brian (2005) "Young People and Family Life: Apocalypse Now or Business as Usual?". Teoksessa Jeremy Roche, Stanley Tucker, Rachel Thomson \& Ronny Flynn (toim.) Youth in Society. Contemporary Theory, Policy and Practice. Lontoo: Sage, The Open University.

Douglas, Mary (1991) “The Idea of Home: A Kind of Space”. Social Research 58:1.

Eagleton, Terry (2011) Why Marx Was Right. New Haven \& Lontoo: Yale University Press.

Erola, Jan (2010) "Luokkarakenne ja luokkiin samastuminen Suomessa". Teoksessa Jan Erola (toim.) Luokaton Suomi? Yhteiskuntaluokat 2000-luvun Suomessa. Helsinki: Gaudeamus, 27-44.

Evans, Brad \& Giroux Henry A. (2015) Disposable Futures. The Seduction of Violence in the Age of Spectacle. San Francisco: City Lights Books.

Foucault, Michel (2008) The Birth of Biopolitics. Lectures at the Collège de France, 1978-1979. Käännös Graham Burchnell. New York: Palgrave Macmillan, 239-265.

Gandal, Keith (2007) Class Representation in Modern Fiction and Film. New York: Palgrave MacMillan.

Giroux, Henry A. (2012) Disposable Youth, Racialized Memories, and the Culture of Cruelty. Lontoo \& New York: Routledge.

Griffin, Christine (1993) Representations of Youth. The Study of Adolescence in Britain and America. Oxford \& Cambridge: Polity Press.

James, David E. (1996) “Introduction: Is There Class in This Text?" Teoksessa David E. James \& Rick Berg (toim.) Hidden Foundation: Cinema and the Question of Class. Minneapolis \& Lontoo: University of Minnesota Press, 1-25.

Kellner, Douglas (1996) "Poltergeist, Gender, and Class in the Age of Reagan and Bush". Teoksessa David E. James \& Rick Berg (toim.) Hidden Foundation: Cinema and the Question of Class. Minneapolis \& Lontoo: University of Minnesota Press, 217-239. 
Kontula, Anna (2016) Luokkalaki. Miten Suomen lait ja viranomaiset syrjivät työväenluokkaa. Helsinki: Into.

Lahikainen, Lauri \& Mäkinen, Katariina (2012) "Luokka erona ja antagonismina". Kulttuurintutkimus 28:4, 3-15.

Lähdesmäki, Tuuli et al. (2016) "Fluidity and Flexibility of "Belonging": Uses of the Concept in Contemporary Research". Acta Sociologica vol. 59:3, 233-247

Pantti, Mervi (2005) “Art or Industry? Battles over Finnish Cinema during the 1990s". Teoksessa Andrew Nestingen \& Trevor G. Elkington (toim.) Transnational Cinema in a Global North. Nordic Cinema in Transition. Detroit: Wayne State University, 165-190.

Read, Jason (2009) "A Genealogy of Homo-Economicus: Neoliberalism and the Production of Subjectivity". Foucault Studies no. 6, 25-36.

Römpötti, Tommi (2012)"Tielle-ja takaisin? Vanhempien odotuksista irtaantuminen elokuvissa Elokuu ja Roskisprinssi". Lähikuva 4, 6-24.

Selkokari, Antti (2010) "Mies tuomitsee itsensä yksin". Aamulehti 29.10.2010.

Skeggs, Beverley (2004) Class, Self, Culture. Lontoo \& New York: Routledge.

Smith, Rachel Greenwald (2015) Affect and the American Literature in the Age of Neoliberalism. New York: Cambridge University Press.

Steinby, Liisa (2008) "Ryöstelijät ammutaan: moderni minä ja mitä sille sitten tapahtui". Teoksessa Jussi Ojajärvi \& Liisa Steinby (toim.) Minä ja markkinavoimat. Yksilö, kulttuuri ja yhteiskunta uusliberalismin valtakaudella. Helsinki: Avain, 25-66.

Suomen elokuvasäätiö (2016) Elokuvavuosi 2015 Facts E Figures, <http://ses.fi/fileadmin/dokumentit/Elokuvavuosi_2015_Facts_Figures.pdf> (linkki tarkistettu 2.1.2017).

Topelius, Taneli (2010) "Kehäpäätelmiä omien ajatusten ympärillä". Turun Sanomat 29.1.2010. Vaarala, Kalle (2010) "Voiko insestin kieltävä isä olla 'ylisuojeleva'?". Karjalainen 28.1.2010.

Varjakoski, Hanna (2015) "'Kai sitä jotenkin hengissä on, kun varjo kulkee vierellä'. Vanhuuskuvia kotimaisessa 2000-luvun elokuvassa". Lähikuva 1, 60-76.

Varto, Juha (2002) Isien synnit. Kasvatuksen kulttuurinen ja biologinen ongelma. Tampere: Tampere University Press.

Verhaeghe, Paul (2014) What about Me? The Struggle for Identity in a Market-Based Society. Melbourne \& Lontoo: Scribe. 